\title{
Occurrence of diamond in peninsular India and its relationship with deep Earth seismic properties
}

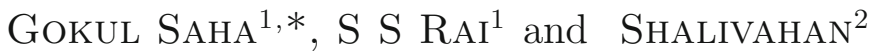 \\ ${ }^{1}$ Department of Earth and Climate Science, Indian Institute of Science Education and Research, Pune, India. \\ ${ }^{2}$ Department of Applied Geophysics, Indian Institute of Technology (Indian School of Mines), Dhanbad, India. \\ *Corresponding author.e-mail: kumarsahagokul123@gmail.com
}

MS received 29 November 2018; revised 22 January 2019; accepted 24 January 2019; published online 21 February 2019

An improved shear wave velocity $\left(V_{\mathrm{s}}\right)$ structure of the lithosphere of peninsular India using the surface wave tomography from the ambient noise and earthquake waveforms suggests its bipolar character. While most of the geological domains of India are characterised by a uniform lithospheric mantle of $V_{\mathrm{s}} \sim 4.5 \mathrm{~km} / \mathrm{s}$, the three cratonic regions, eastern Dharwar, Bastar and Singhbhum, hosting most of the diamondiferous kimberlite fields, show significantly high $V_{\mathrm{s}}$ of $4.7 \mathrm{~km} / \mathrm{s}$ and above in their lower lithosphere beyond $\sim 90 \mathrm{~km}$ depth. The higher velocity could best be explained by the presence of diamond and/or eclogite along with peridotite in mantle. This unique relationship suggests the regional seismic image of lithosphere as a guide for exploration of diamonds.

Keywords. Daimond; kimberlite; craton; surface wave; tomography.

\section{Introduction}

Diamonds are a crystallised form of carbon that grow from a primary carbon source subjected to very high temperatures (about $1000^{\circ} \mathrm{C}$ ) and pressure (45-60 kbar) equivalent to a burial depth of about $150 \mathrm{~km}$ below the Earth's surface, often known as the diamond stability zone (Shchipansky 2012). Once formed, diamonds are brought to the surface of the Earth through volcanic eruption. The rock type produced by these volcanic activities is known as kimberlite. It has long been known that diamond-bearing kimberlite pipes are related largely to Archaean cratons. In rare cases, diamonds can be found in lamproite potash-rich highmagnesium volcanic rocks similar to kimberlite.
The genesis of diamonds is closely related to the presence of peridotite (both lherzolite and harzburgite) and eclogite, which are derived from the upper mantle below cratonic areas. Cratonic eclogites are strongly concentrated at the base of the depleted subcontinental lithospheric mantle (SCLM) or at major layer boundaries and are accompanied by intense melt-related metasomatism in adjacent peridotites (Griffin and O'Reilly 2007). The lithosphere is the outermost rigid part of the Earth that is in coherent motion with the Earth's surface. It comprises the crust and the shallower mantle to a depth of $150-200 \mathrm{~km}$. Mapping of detailed seismic structure of the lithospheric mantle and cratonic roots is, therefore, important to understand the geodynamics of the

Supplementary material pertaining to this article is available on the Journal of Earth System Science website (http://www. ias.ac.in/Journals/Journal_of_Earth_System_Science). 
region and may serve as a guide for diamond exploration.

India, known for world famous diamonds such as the Great Moghul, the Kohinoor, etc., is a diamond-deficient country with the known ancient and recent mining confined to a few cratonic domains such as the eastern Dharwar craton (EDC), the Bastar, the Singhbhum and the Bundelkhand. In these terrains over 200 kimberlites, lamproites, ultramafic lamprophyres and other alkaline bodies are known (figure 1). These diamonds and non-diamondiferous host rock locations are almost continuous and interestingly follow a well-defined geographical trend.

In this communication, we attempt to understand the linkage of diamondiferous kimberlite distribution with seismic shear wave velocity image of the lithosphere beneath Precambrian terrains of India created using improved Rayleigh wave group velocity images. The magnitude of shear wave velocity places bounds on the plausible range of temperatures and compositions, while the shape of the velocity profiles, as a function of depth, constraints the thermal and chemical gradients. We discuss the morphology of the Archaean upper mantle seismic wave velocity and its spatial relationship with the known kimberlite fields. These results present a new geologic model that explains the distribution of diamondiferous kimberlites relative to the cratonic nuclei.

\section{Geology of peninsular India}

Peninsular India is an amalgamation of Archaean cratonic nuclei (the Aravalli-Bundelkhand, the

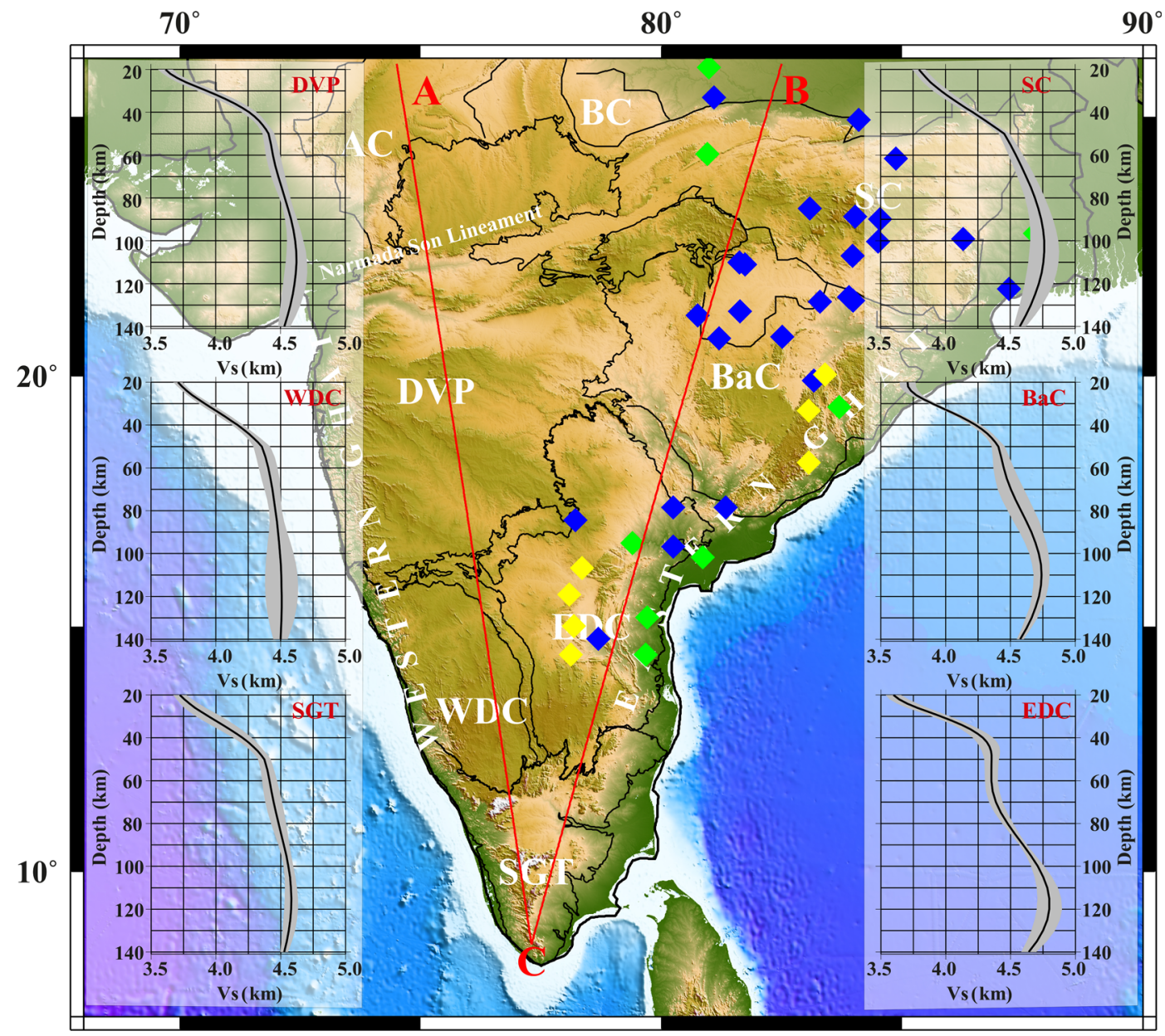

Figure 1. Geological map of the study area showing main tectonic regions along with the location of old diamond mines (blue diamond), kimberlite (yellow diamond) and lamproite (green diamond) (Ref: Unlocking India's mineral wealth, https:// mines.gov.in/GSI_PDAC_2013.pdf). Major geological features are as follows: AC: Aravalli craton; SC: Singhbhum craton; BaC: Bastar craton; EDC: eastern Dharwar craton; WDC: western Dharwar craton; SGT: southern granulite terrain; DVP: Deccan Volcanic Province. Locations of two representative profiles showing velocity-depth sections are also shown as red lines. The average one-dimensional (1D) shear wave velocity for different geological terrains is presented. 
Singhbhum, the Bastar, the western Dharwar and the EDC) interspersed with several Precambrian mobile belts and basins (Naqvi and Rogers 1987). The Dharwar, the Bastar and the Singhbhum are believed to form a supercraton that joined with the Aravalli-Bundelkhand cratons during the ca. 1000 Ma orogenic processes. Although the cratons have an evolutionary history of $\sim 4.2 \mathrm{Ga}$, they stabilised close to $2.5 \mathrm{Ga}$. Later, tectonic activities include Proterozoic basin evolution and kimberlite volcanism between 1.8 and $1.1 \mathrm{Ga}$, Pan-African tectonism at $\sim 550 \mathrm{Ma}$, separation from Madagascar at $\sim 90 \mathrm{Ma}$, Deccan volcanism at $\sim 65 \mathrm{Ma}$ and concurrent separation from Seychelles.

The Aravalli craton occupies the north-western part of the peninsular India of $\sim 3.5$ Ga age. Further east, the Bundelkhand massif $(2.6 \mathrm{Ga})$ is a triangular segment of the Indian shield bounded by the Narmada-Son lineament in the south, the great boundary fault of the Aravalli range in the west and the Ganga basin in the north. The eastern part of India comprises the Singhbhum craton, one of the oldest Archaean ( $\sim 4.2 \mathrm{Ga})$ cratonic nuclei and is bounded by the Mahanadi Graben and the Bastar craton. Southern India hosts the extensively studied western Dharwar craton (WDC) and the EDC separated by $\mathrm{N}-\mathrm{S}$ elongated Chitradurga shear zone. The WDC is made up of 3.3-3.0 Ga gneisses and greenstone belt with $\sim 2.5$ Ga granite inclusions. It shows an increasing degree of metamorphism and exposes rocks from 3 to $5 \mathrm{kbar}$ and $500^{\circ} \mathrm{C}$ (greenschist facies) in the north to $8 \mathrm{kbar}$ and $800^{\circ} \mathrm{C}$ (granulite facies) in the south. The EDC is dominated by late Archaean $(\sim 2.7 \mathrm{Ga})$ calcalkaline complex of juvenile and anatectic granites, granodiorites and diorites. It is bounded to the north by the Deccan basalt and the Bastar craton, to the east by the eastern Ghats mobile belt and the Proterozoic $(\sim 1.8-0.7 \mathrm{Ga})$ Cuddapah basin (CB) and to the south by the southern Granulite terrain (SGT; see figure 1 for more details).

\section{Geochemical signature of kimberlite xenoliths}

We briefly present the salient geochemical characteristics of diamondiferous kimberlites from the three geological domains. Kimberlite xenoliths have been studied extensively using mineralogical, thermobarometric and geochemical approach (Karmalkar et al. 2009; Chalapathi Rao et al. 2013; Dongre et al. 2015). The eclogite xenoliths from the eastern Dharwar kimberlite cluster show temperature and pressure ranging from 1020 to $1225^{\circ} \mathrm{C}$ and 56-61 kbar with a depth of $176-191 \mathrm{~km}$ at $\sim 1.1$ Ga. Major trace elements, as well as the oxygen isotopes of eclogite xenoliths from this area, show strong positive Eu anomalies in garnet and positive $\mathrm{Eu}$ and $\mathrm{Sr}$ anomalies in the reconstructed whole rock trace element patterns. Similar to many other eclogite suites worldwide, eclogite from EDC suites shows an evidence for its origin linked to oceanic crust subducted and imbricated under the EDC.

Analysis of mantle xenoliths from the diamondiferous kimberlite pipe of the Bastar craton, central India, suggests rare features of decompression melting of garnet lherzolite xenoliths that have a mode of $15 \%$ garnet $\left(8 \% \quad \mathrm{Cr}_{2} \mathrm{O}_{3}\right), 30 \%$ olivine (Fog1), 25\% cpx (2-4\% $\left.\mathrm{Na}_{2} \mathrm{O}\right), 12 \%$ opx (Mg\# 0.89) with $15 \%$ melt and 3\% secondary Cr-spinel (EVSSK Babu, personal communication, unpublished data). The core composition of the different phases indicates $P$ and $T$ range of 4.3-4.7 GPa and $1140-1270^{\circ} \mathrm{C}$. They interpret the formation of $\mathrm{Cr}$-spinel within the glass pockets due to the melting of the xenoliths in a rising kimberlite column close to the garnet-spinel transition in the SCLM. More recently discovered that the youngest (59.5 Ma) Jharkhand kimberlites close to the contact of the Bastar and the Singhbhum craton are rich in eclogites.

\section{Previous lithospheric studies}

We discuss below the current state of knowledge related to individual segments of the study region based largely on the seismological, heat flow and xenolith studies. The shear wave velocity structure of the Indian crust reveals significant diversity (Julia et al. 2009; Das and Rai 2017). In peninsular India, the Moho depth varies within a range of 33-40 km with a few local variations such as the WDC and the Aravalli-Delhi belt where it is 45$52 \mathrm{~km}$. Beneath most part of the Indian crust, a 10to $15-\mathrm{km}$ thick, high-velocity layer $\left(V_{\mathrm{s}} \geq 4.0 \mathrm{~km} / \mathrm{s}\right)$ is mapped above the Moho.

Lithospheric studies based on surface waveform analysis (Acton et al. 2010; Maurya et al. 2016) suggest lithospheric thickness variations from about $120 \mathrm{~km}$ in the southernmost part of India, increasing progressively to $160-180 \mathrm{~km}$ in the Dharwar and the Singhbhum cratons and 200 $250 \mathrm{~km}$ in the northern India. They found a shear 
wave velocity close to $4.5 \mathrm{~km} / \mathrm{s}$ from the Moho down to a depth of $\sim 250 \mathrm{~km}$. The most conspicuous feature of these studies is the absence of a high-velocity keel $\left(V_{\mathrm{s}} \sim 4.7 \mathrm{~km} / \mathrm{s}\right)$ beneath the Indian lithospheric mantle observed in many other Archaean cratons world over.

Roy and Mareschal (2011) used constraints from seismic shear wave velocity profiles, geothermobarometry estimates on mantle xenoliths, and surface heat flux and heat production measurements to analyse the thermal regime of lithosphere beneath India. They suggest that the shear wave velocities are highest beneath north-central India that cannot be explained by variations in mantle temperature but require differences in mantle composition. Thermobarometric analysis of xenoliths derived from kimberlite samples suggests a thick lithosphere beneath the Dharwar craton $(\sim 185 \mathrm{~km}$ at $\sim 1.0 \mathrm{Ga})$ and the Bastar craton $(\sim 175 \mathrm{~km}$ at $\sim 65 \mathrm{Ma}$ ). Due to limited and geographically skewed geophysical datasets, the studies discussed above could not be used to develop a coherent velocity images and their linkage with surface features.

\section{Velocity modelling methodology}

We present here an improved and coherent shear wave seismic velocity image of the crust and uppermost mantle (up to $140 \mathrm{~km}$ depth) of peninsular India using Rayleigh wave group velocity measurements. The shear velocity variation with depth at any location is computed by first creating a group velocity map of the region at time periods from 10 to $70 \mathrm{~s}$ and then inverting these group velocitytime period data. Location of seismological stations and earthquakes used for the group velocity creation is shown in figure $\mathrm{S} 1$.

\subsection{Group velocity tomography}

The Rayleigh wave group velocity tomography of the region is achieved in two steps. First, we compute the group velocity along several paths in the region at various time periods using surface wave retrieved from cross-correlation of interstation ambient noise data (Bensen et al. 2007). As an example, the cross-correlation function at a station for different distances is shown in figure 2(A). We also used selected earthquake waveforms recorded over seismic stations to improve ray density and hence the horizontal resolution. The
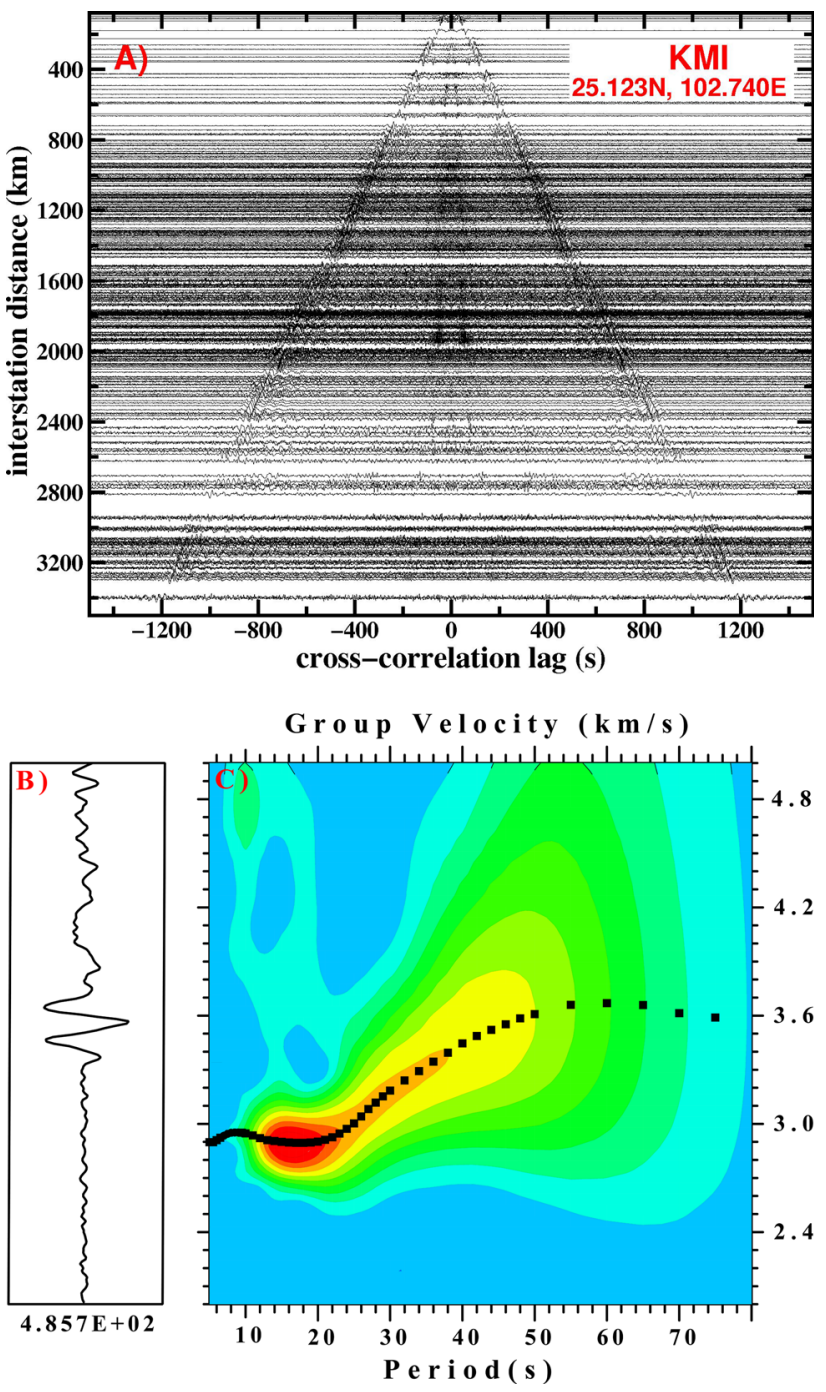

Figure 2. (A) An example of Rayleigh wave crosscorrelation function (CCF) for station KMI (25.123N, 102.740E). A stacked symmetric CCF and its corresponding dispersion curve for a particular station pair CHTO (18.814N, 98.944E)-KMI (25.123N, 102.740E) are shown in (B) and (C).

group velocity between pairs of seismic stations for ambient noise data and earthquake to seismic stations is computed using the multiple filter technique (Herrmann and Ammon 2004). A stacked symmetric cross-correlation function and its corresponding dispersion curve for a particular path are shown in figure $2(\mathrm{~B}$ and $\mathrm{C})$. We select only the group velocity measurements with $\mathrm{S} / \mathrm{N}>15$ and inter-station distance more than three times the wavelength at the considered period (Bensen et al. 2008). These Rayleigh wave travel-time dispersion data from multiple paths are then converted into group velocity maps for time periods in the range of $10-70 \mathrm{~s}$ at every 5 -s interval following Barmin 


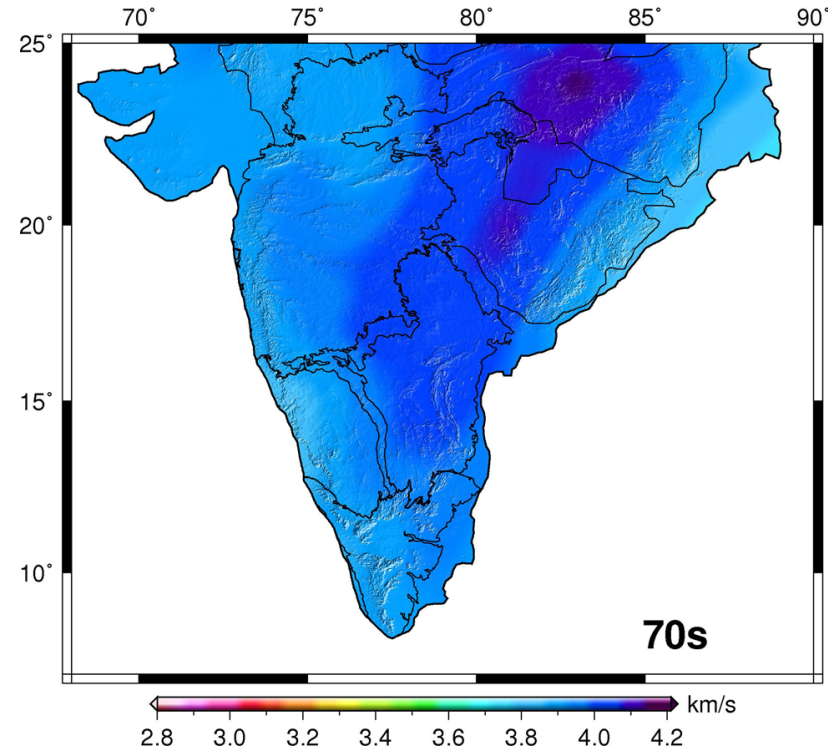

Figure 3. Fundamental mode Rayleigh wave group velocity map for the peninsular India at a time period of $70 \mathrm{~s}$.

et al. (2001). A representative group velocity map of the region at 70 -s time period is presented in figure 3 .

The spatial resolution of group velocity map at selected time period is computed through a synthetic reconstruction using checkerboard resolution test considering the synthetic model comprising squares with an alternating pattern of higher and lower wave velocity in two dimension (2D) or three dimension (3D; Rawlinson abd Spankman 2016). We experimented with cells of various sizes for checkerboard test at 10-, 30- and 70-s Rayleigh waves with a velocity perturbation of $\pm 6 \%$ assigned to each cell relative to average velocity at each period. The highest resolved $1^{\circ} \times 1^{\circ}$ checkerboard for a particular time period $(70 \mathrm{~s})$ is presented in figure 4 . For other time periods, the resolution test is presented in figure S2. The checkerboard spikeperturbation test shows a horizontal resolution of $\sim 100 \mathrm{~km}$ for most parts of the study region. The group velocity map corresponding to other time periods is presented in figure S3.

\subsection{Shear wave velocity models}

We have constructed the shear wave velocity-depth model from the Rayleigh wave group velocity at each of $1^{\circ} \times 1^{\circ}$ node through a linearised inversion scheme developed by Herrmann and Ammon (2004). The starting model for the inversion consists of stack of isotropic layers with constant shear wave $V_{\mathrm{s}}$ of $4.50 \mathrm{~km} / \mathrm{s}$. The layer thickness is $1 \mathrm{~km}$

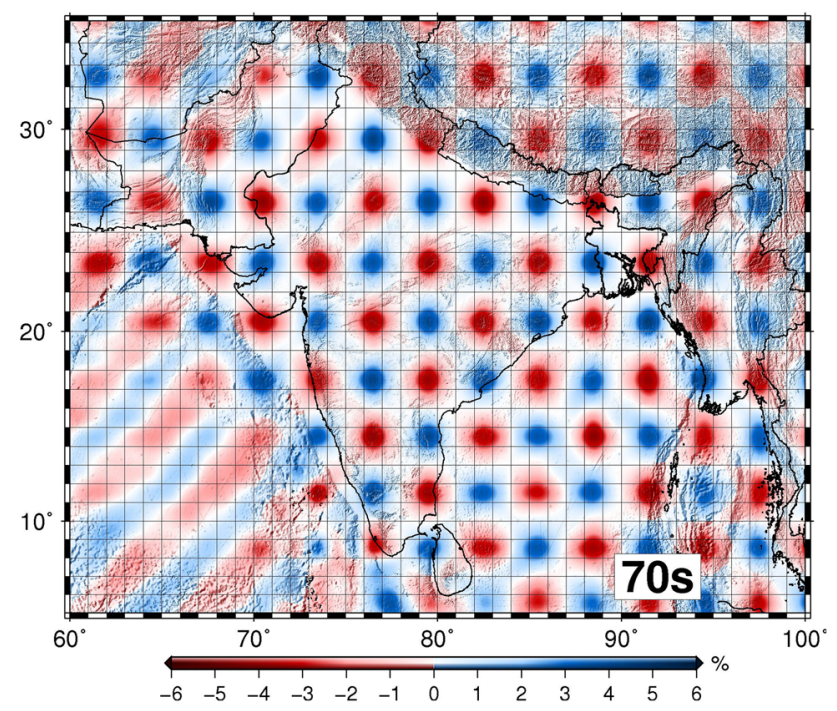

Figure 4. Chequerboard recovery test for Rayleigh wave group velocity period of $70 \mathrm{~s}$ with a cell size of $1^{\circ} \times 1^{\circ}$. The input model is a cell with alternating $\pm 6 \%$ velocity variation relative to an average for the region.

up to $10 \mathrm{~km}$ depth, followed by 2 -km-thick layers from 10 to $50 \mathrm{~km}$ depth and finally layers with 5 -km thickness extending from 50 to $140 \mathrm{~km}$ depth. We repeated inversion 20 times for all the nodes to get the final $V_{\mathrm{s}}$ model. As an example, we present the averaged group velocity dispersion curve for Bastar craton and the corresponding inverted model in figure S4. At many other locations, we compared our inverted model with published results of Mitra et al. (2006), Julia et al. (2009) and Acton et al. (2010) and found to be nearly the same. These models are then stitched to generate the shear wave velocity images at different depths from the surface down to a depth $140 \mathrm{~km}$.

We present the shear wave velocity-depth sections along with two selected south to north profiles (figure 5). Considering that the focus of this study is linking lithosphere structure to the diamond occurrences, we restrict detailed analysis of our velocity result to sub-crustal depth only. The most interesting part of our study is the observation of $>4.7 \mathrm{~km} / \mathrm{s}$ velocity layer beneath three diamondbearing kiberlite regions of the EDC, the Bastar craton and the Singhbhum craton. This high velocity is observed in depth from $90 \mathrm{~km}$ to at least $140 \mathrm{~km}$. Its deeper extent cannot be accurately mapped due to limited time period of Rayleigh wave data. Its presence was also indicated in Acton et al. (2010) but could not be mapped accurately due to lateral averaging. The lithospheric mantle, elsewhere in India, has $V_{\mathrm{s}}$ of $4.5 \mathrm{~km} / \mathrm{s}$. To further 


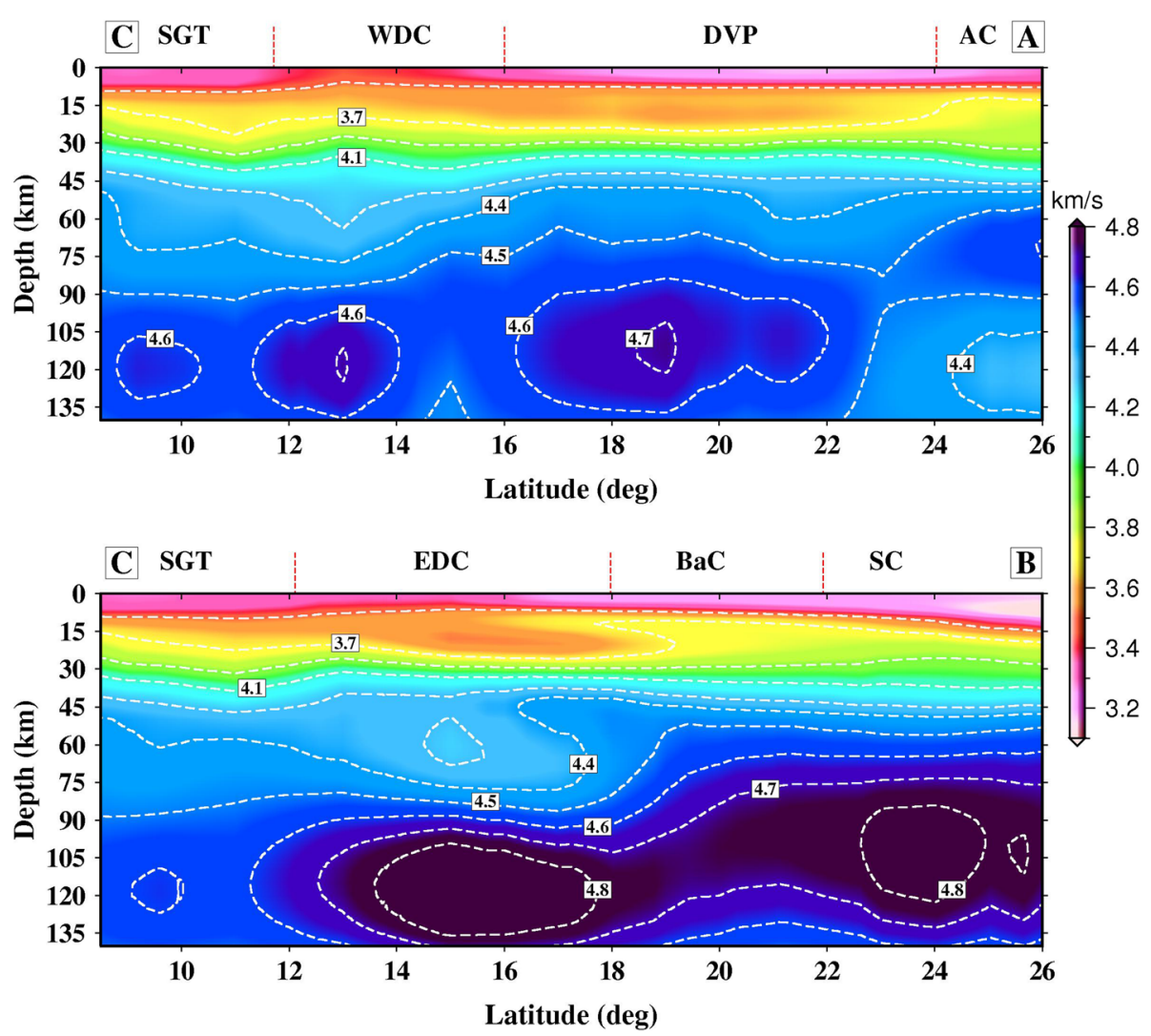

Figure 5. Shear wave velocity-depth section from south to north. Location of two profiles is shown in figure 1. Major geological domains and tectonic boundaries are marked on top of individual figures. Note the significant higher shear velocity of more than $4.7 \mathrm{~km} / \mathrm{s}$ beneath the EDC, the Bastar craton and the Singhbhum craton.

emphasise the differences in upper mantle velocity structure among terrains, we stacked all the data in each of terrains to form an average velocitydepth image along with bounds. This is presented in figure 1. The results show enhanced lithospheric mantle velocity beneath the EDC, the Bastar craton and the Singhbhum craton compared to all other geological domains.

\section{Discussion}

Global seismic models show clearly that the cratonic upper mantle is characterised by higher wave velocity than non-cratonic mantle to depths of at least $200 \mathrm{~km}$. In the depth of 100-150 km, the Archaean and Proterozoic terrains have distinct $V_{\mathrm{s}}$ of 4.6 and $4.5 \mathrm{~km} / \mathrm{s}$, respectively. The S-velocity in Archaean terrain reduces progressively to $4.5 \mathrm{~km} / \mathrm{s}$ at $200 \mathrm{~km}$.

We summarise results from the velocity image of peninsular India. Most parts of India, except for the three cratons (EDC, Bastar and Singhbhum are characterised by a simple uppermost mantle model of $V_{\mathrm{s}} \sim 4.5 \mathrm{~km} / \mathrm{s}$, similar to those observed over Kaapvaal craton, South Africa. Such a velocity can be explained by the peridotite composition of the uppermost mantle considering a steady-state conductive geotherms of $40 \mathrm{~mW} / \mathrm{m}^{2}$ (Garber et al. 2018). The three cratons, the EDC, the Bastar and the Singhbhum, forming more than 1200-kmlong diamond corridor in the eastern-southeastern part of India show a significantly higher velocity of $\sim 4.75 \mathrm{~km} / \mathrm{s}$ in the depth of $90-130 \mathrm{~km}$. Similar higher velocity is observed over many Archaean cratons (Garber et al. 2018). This inference is also supported by regional earthquake travel-time data recorded over peninsular India, suggesting that Sn velocity in the shallower mantle is less than $4.7 \mathrm{~km} / \mathrm{s}$, while at greater depths, the velocity is greater than $4.7 \mathrm{~km} / \mathrm{s}$ for a distance greater than $700 \mathrm{~km}$. The velocity at depth from the Moho to $\sim 90 \mathrm{~km}$ is similar to other cratons, i.e., $4.5 \mathrm{~km} / \mathrm{s}$ (Mitra et al. 2006).

A peridotite composition of the mantle at $150 \mathrm{~km}$ depth spanned by Archaean peridotites is characterised by shear wave velocity $4.5-4.6 \mathrm{~km} / \mathrm{s}$. The velocity variation is primarily attributed to the 
change of mantle temperature or its composition. The $V_{\mathrm{s}}$ variations of $\pm 3 \%$ over distances of a few hundred kilometres as observed in our model can be obtained with temperature variations of about $400 \mathrm{~K}$. However, the observed surface heat flow over India does not show any such significant variation in the mantle heat flow contribution (Roy and Mareschal 2011). The other cause for the increase in velocity could be the compositional variation in the mantle rocks. The variations in composition inferred from mantle xenoliths usually do not change the velocity larger than 1\%. Also, with increasing melt $\%$, the $V_{\mathrm{s}}$ changes up to $\pm 1 \%$. Seismological studies accounting for the radial anisotropy of minerals show that the high-shear wave velocity structure $\left(V_{\mathrm{s}} \sim 4.7 \mathrm{~km} / \mathrm{s}\right)$ beneath cratons cannot be matched solely by peridotite in the depth range $\sim 100-170 \mathrm{~km}$ (Hirsch et al. 2015).

Garber et al. (2018) proposed the increase in the amount of garnet or eclogite in the mantle to explain the increased shear wave velocity $(>4.7 \mathrm{~km} / \mathrm{s})$ of cratons. Based on modelling of several possible mineral compositions, they suggest that the presence of eclogite and/or diamond is responsible for the high $V_{\mathrm{s}}$ in cratonic roots with $\sim 1-3$ vol. $\%$ diamond or $>>20$ vol. $\%$ eclogite added to peridotite. Detailed quantification of the amount of diamond or eclogite needed to explain the observed $V_{\mathrm{s}}$ requires further analysis. Kimberlite studies favoured the idea that eclogite could be abundant in the interior of the Earth. In most cases, the eclogites are concentrated in a 10- to $15-\mathrm{km}$-thick layer. If this layer consists of $30-50 \%$ eclogite, then the proportion of eclogite, averaged over a garnet-bearing SCLM 100- to 200-km thick, would be a few percentages, consistent with the existing estimates.

In the context of India, the presence of eclogite and/or diamond along with peridotite could be a viable proposition to explain the observed highvelocity mantle beneath the EDC, the Bastar and the Singhbhum that once formed a supercontinent. As discussed above, several studies provide credible evidence for the presence of eclogite in the mantle along the diamond corridor of India. Eclogites having distinct high velocity and absence of anisotropy (Worthington et al. 2013) leave their distinct imprint in the seismic wave velocity and hence could be used as a path finder for diamond exploration. This, however, requires a high-resolution seismic image of the lithospheric mantle which is the subject of our new study.

\section{Acknowledgements}

Indian seismological data were provided by CSIRNGRI and CSIR-4PI Institute. We thank the two institutes for their support. The seismic waveform data from other stations were obtained from IRIS Data Management Center. This research was supported by the Ministry of Earth Sciences grant MoES/PO (Geosci)/58/2016 titled 'Multiscale deep geology of India-Eurasia region and adjoining sea' and the Department of Science and Technology (JC Bose National fellowship to SSR) of the Government of India. SSR thanks Dr Babu (NGRI) for providing unpublished geochemical data and research abstract for the Bastar kimberlite field.

\section{References}

Acton C E, Priestley K, Gaur V K and Rai S S 2010 Group velocity tomography of the Indo-Eurasian collision zone; J. Geophys. Res. Solid Earth 115 B12335, https://doi. org/10.1029/2009JB007021.

Barmin M P, Ritzwoller M H and Levshin A L 2001 A fast and reliable method for surface wave tomography; Pure Appl. Geophys. 158 1351-1375.

Bensen G D, Ritzwoller M H and Shapiro N M 2008 Broadband ambient noise surface wave tomography across the United States; J. Geophys. Res.: Solid Earth 113(B5).

Bensen G D, Ritzwoller M H, Barmin M P, Levshin A L, Lin F, Moschetti M P, Shapiro N M and Yang Y 2007 Processing seismic ambient noise data to obtain reliable broad-band surface wave dispersion measurements; Geophys. J. Int. 169 1239-1260.

Chalapathi Rao N V, Lehmann B, Belousova E, Frei D and Mainkar D 2013 Petrology, bulk-rock geochemistry, indicator mineral composition and zircon U$\mathrm{Pb}$ geochronology of the end-cretaceous diamondiferous Mainpur orangeites, Bastar craton, central India; In: Proceedings of 10th International Kimberlite Conference (eds) Pearson D G et al., Vol. 1, J. Geol. Soc. India, https:// doi.org/10.1007/978-81-322-1170-9_7.

Das R and Rai S S 2017 Extensive seismic anisotropy in the lower crust of Archean metamorphic terrain, south India inferred from ambient noise tomography; Tectonophys. 694 164-180.

Dongre A N, Jacob D E and Stern R A 2015 Subduction related origin of eclogite xenoliths from the Wajrakarur kimberlite field, Eastern Dharwar craton, southern India: Constraints from petrology and geochemistry; Geochim. Cosmochim. Acta 166 165-188, https://doi.org/10.1016/ j.gca.2015.06.023.

Garber J M, Maurya S, Hernandez J A, Duncan M S, Zeng L, Zhang H L, Faul U, McCammon C, Montagner J P, Moresi L and Romanowicz B A 2018 Multidisciplinary constraints on the abundance of diamond and eclogite in the cratonic lithosphere; Geochem. Geophys. Geosyst. 19 2062-2086, https://doi.org/10.1029/2018GC007534. 
Griffin W L and O'Reilly S Y 2007 Cratonic lithospheric mantle: Is anything subducted? Episodes 30 43-53.

Herrmann R B and Ammon C J 2004 Surface wave, receiver function, and crustal structure; Computer programs in seismology, version 3.30, St. Louis University.

Hirsch A C, Dalton C A and Ritsema J 2015 Constraints on shear velocity in the cratonic upper mantle from Rayleigh wave phase velocity; Geochem. Geophys. Geosyst. 16 3982-4005.

Julia J, Jagadeesh S, Rai S S and Owens T J 2009 Deep crustal structure of the Indian shield from joint inversion of $\mathrm{P}$-wave receiver functions and Rayleigh wave group velocities: Implications for Precambrian evolution; J. Geophys. Res. 114 B10313, https://doi.org/10.1029/ 2008JB006261.

Karmalkar N R, Duraiswami R A, Chalapathi Rao N V and Paul D K 2009 Mantle derived mafic-ultramafic xenoliths and the nature of Indian subcontinental lithosphere; $J$. Geol. Soc. India 73 657-679.

Maurya S, Montagnier J P, Kumar M R, Stutzmann E, Kiselev S, Burgos G, Rao N P and Srinagesh D 2016 Imaging the lithospheric structure beneath the Indian continent; J. Geophys. Res.: Solid Earth 121 7450-7468.
Mitra S, Priestley K, Gaur V K and Rai S S 2006 Shear-wave structure of the south Indian lithosphere from Rayleigh wave phase-velocity measurements; Bull. Seismol. Soc. Am. 96(4A) 1551-1559.

Naqvi S M and Rogers J J W 1987 Precambrian geology of India; Oxford University Press, New York, 223p.

Rawlinson N and Spankman W 2016 On the use of sensitivity tests in seismic tomography; Geophys. J. Int. 205 12211243 .

Roy S and Mareschal J C 2011 Constraints on the deep thermal structure of the Dharwar craton, India, from heat flow, shear wave velocities, and mantle xenoliths; J. Geophys. Res. 116 B02409, https://doi.org/10.1029/ 2010JB007796.

Shchipansky A A 2012 Subduction geodynamics in Archean and formation of diamond-bearing lithospheric keels and early continental crust of cratons; Geotectonics (Moscow) 46 122-141, https://doi.org/10.1134/ S0016852112020057.

Worthington J R, Bradley R H and Zandt G 2013 Distinguishing eclogite from peridotite: EBSD-based calculations of seismic velocities; Geophys. J. Int. 193 489-505.

Corresponding editor: N V ChALAPATHI RAO 